\title{
Histamine production by Enterobacter aerogenes in chub mackerel (Scomber japonicus) at various storage temperatures
}

\author{
Yu ZOU ${ }^{1 *}$, Xiyan HOU ${ }^{1}$
}

\begin{abstract}
Growth of Enterobacter aerogenes and accumulation of histamine in chub mackerel (Scomber japonicus) were investigated through measuring bacterial count, histidine decarboxylase (HDC) activity and histamine content in fish samples stored at various temperatures from 4 to $37^{\circ} \mathrm{C}$. Results showed that bacterial count and HDC activity rapidly increased in chub mackerel inoculated with E. aerogenes at storage temperature above $20^{\circ} \mathrm{C}$ and reached the highest values $(8.64 \log \mathrm{CFU} / \mathrm{g}$ and $31.68 \mathrm{U} / \mathrm{g}$ ) at $37^{\circ} \mathrm{C}$. Meanwhile, fish samples stored at 25 and $37^{\circ} \mathrm{C}$ for $18 \mathrm{~h}$, formed histamine at above $50 \mathrm{mg} / 100 \mathrm{~g}$ of the potential hazard level. In contrast, bacterial growth and histamine formation were controlled for $36 \mathrm{~h}$ by cold storage at low temperature $\left(4^{\circ} \mathrm{C}\right)$. Therefore, strict temperature control was necessary for preservation and processing of chub mackerel in order to assure this marine fish safety.
\end{abstract}

Keywords: histamine; histidine decarboxylase; Enterobacter aerogenes; chub mackerel.

Practical Application: This survey allows knowing histamine accumulation in chub mackerel at various storage temperatures.

\section{Introduction}

The presence of histamine in food is of concern to researchers, consumers, food companies, and health authorities due to its toxicological effects. Histamine at high concentration can cause histamine poisoning which typically lasts up to $24 \mathrm{~h}$ producing allergy-like symptoms such as facial flushing, nausea and headache (Naila et al., 2012; Rodtong et al., 2005). The accumulation of histamine in food is a result of bacterial histidine decarboxylase (HDC, EC 4.1.1.22), which catalyzes the decarboxylation of 1-histidine to form histamine (Torido et al., 2012). These foods include fisheries products, cheese, wine and other fermented products (Konagaya et al., 2002).

Many bacterial species are known to possess histidine decarboxylase and have the ability to produce histamine. Most of them have been identified as the enteric bacteria that include Proteus vulgaris, Proteus mirabilis, Enterobacter aerogenes, Enterobacter cloacae, Serratia fonticola, Serratia liquefaciens and Citrobacter freundii (Hsu et al., 2009; Rodtong et al., 2005). Among these enteric bacteria, E. aerogenes is reported as the main causes of histamine poisoning (Kim et al., 2009). The tuna dumpling stuffing contaminated with E. aerogenes store at $25^{\circ} \mathrm{C}$ for $12 \mathrm{~h}$, formed histamine will be above $50 \mathrm{mg} / 100 \mathrm{~g}$ of the potential hazard level in most illness cases (Lee et al., 2012). Therefore, E. aerogenes also is considered to be the strongest histamine-producing bacterium.

Chub mackerel (Scomber japonicus) is international middle-sized pelagic species with a wide distribution in many parts of the world (Bae \& Lim, 2012). It is one of the most important fishing resources in China. Chub mackerel is widely consumed by humans because it has high protein and low saturated fat (Li et al., 2014). As one of the scombroid fishes, chub mackerel contains high levels of free l-histidine in their muscle and is often implicated in scombroid poisoning incidents, which make this marine fish to be a potentially hazardous food. This emphasises the importance of good hygiene controls when preservation and processing of chub mackerel.

There have been reports about the research on histamine production in chub mackerel during storage in previous literature (Bae \& Lim, 2012; Fadhlaoui-Zid et al., 2012). However, there is no report focused on behavior of strong histamine-producing bacteria in relation to HDC activity and the amount of histamine. In this study, bacterial count, HDC activity and histamine content in chub mackerel inoculated with E. aerogenes stored at various temperatures were investigated in order to better understand the mechanism of histamine formation in marine fish and avoid food poisoning caused by histamine.

\section{Materials and methods}

\subsection{Material}

Frozen chub mackerel (Scomber japonicus) with an average weight of $380 \pm 10 \mathrm{~g}$ were obtained from Dalian aquatic market (Dalian, Liaoning province, China) during January and April 2015. They were defrosted immediately before inoculation, and used in the study. The bacterial strain E. aerogenes DL-1, a strong histamine-producing bacterium previously isolated from chub mackerel, were used for inoculation. Stock cultures were maintained on trypticase soy agar slants and subcultured every month. Histamine and l-histidine were obtained from 
Sigma-Aldrich Chemicals Co. (St. Louis, USA). All other chemicals and reagents used in the experiment were of analytical grade.

\subsection{Inoculation of bacteria}

The frozen fish was defrosted, and the fish sample was cut into small pieces and inoculated with the bacteria to a final concentration of $1 \times 10^{3} \mathrm{CFU} / \mathrm{g}$. The inoculated fish sample was stored at various temperatures $\left(4,20\right.$, and $\left.37^{\circ} \mathrm{C}\right)$. Bacterial count, HDC activity, and histamine content were measured after $0,6,12,18,24,30$ and $36 \mathrm{~h}$ of storage. The experiment was repeated three times.

\subsection{Microbial colony count}

Ten grams of fish sample was homogenized at $4{ }^{\circ} \mathrm{C}$ for 2 min in a sterile blender (BL25C46, Guangdong Midea Electric Appliances Co., Ltd., Foshan, China) with $90 \mathrm{~mL}$ of sterile distilled water. After the homogenate was serially diluted with sterile distilled water, $0.1 \mathrm{~mL}$ aliquots of dilutes were spread plated on trypticase soy agar plate containing $0.5 \% \mathrm{NaCl}$. The agar plates were shifted to an incubator (DNP-9052, Shanghai Jinghong Laboratory Apparatus Co., Ltd, Shanghai, China) at $37^{\circ} \mathrm{C}$ for $2 \mathrm{~d}$. Colonies in samples were counted by multiplying with reciprocal. The results were expressed as log colony-forming units $\left(\log _{10} \mathrm{CFU} / \mathrm{g}\right)$ of sample.

\subsection{HDC activity assay}

Assessment of HDC activity was performed by the method previously described by Zou et al. (2015). The fish sample was homogenized as described above. The homogenate was disrupted with an ultrasonic disintegrator (JT-100, Ningbo Scientz Biotechnology Co., Ltd., Ningbo, China) at $250 \mathrm{~W}$ for $20 \mathrm{~min}$ at $4{ }^{\circ} \mathrm{C}$ and the cell-free extract was obtained by centrifugation (10,000 rpm, $20 \mathrm{~min})$. A proper volume of the cell-free extract was added to the reaction solution containing $10 \mathrm{mM}$ l-histidine (used as the substrate), $1 \mathrm{mg} / \mathrm{mL}$ bovine serum albumin and $0.1 \mathrm{M}$ phosphate buffer ( $\mathrm{pH}$ 6.8), and the reaction was allowed to proceed for $15 \mathrm{~min}$ at $37^{\circ} \mathrm{C}$. The reaction was stopped by adding $4 \mathrm{M}$ perchloric acid, followed by centrifugation at $4,000 \mathrm{rpm}$ for $5 \mathrm{~min}$ and the resulting reaction mixture was extracted with $n$-butanol containing $5 \mathrm{M} \mathrm{NaOH}$ and $5 \mathrm{M} \mathrm{NaCl}$. After neutralization, $1 \mathrm{~mL}$ of the resulting reaction mixture was added to the detection solution containing $1 \mathrm{M} \mathrm{NaOH}$ and $o$-phthalaldehyde and the relative fluorescence was measured by a fluorescence spectrometer (RF-5301, Shimadzu Co., Kyoto, Japan) at an excitation wavelength of $360 \mathrm{~nm}$ and emission wavelength of $450 \mathrm{~nm}$.

\subsection{Determination of histamine content}

Ten grams of fish sample was homogenized with $90 \mathrm{~mL}$ of $5 \%$ trichloroacetic acid at $4{ }^{\circ} \mathrm{C}$ for $2 \mathrm{~min}$. After being centrifuged (10,000 rpm) for $20 \mathrm{~min}$ at $4{ }^{\circ} \mathrm{C}$, the supernatant was collected and derivatized based on a modified method (Hu et al., 2012). Briefly, $0.5 \mathrm{~mL}$ of supernatant was firstly mixed with $100 \mu \mathrm{L}$ of $2 \mathrm{M}$ sodium hydroxide to adjust the $\mathrm{pH}$ to 9.5 , then reacted with $1 \mathrm{~mL}$ of $10 \mathrm{mg} / \mathrm{mL}$ dansyl chloride at $60^{\circ} \mathrm{C}$ for $30 \mathrm{~min}$ for derivatisation. Then, the reactant was mixed with $100 \mu \mathrm{L}$ of $25 \%$ ammonium hydroxide and incubated at $60{ }^{\circ} \mathrm{C}$ for $30 \mathrm{~min}$ to remove the residual dansyl chloride. The mixture was adjusted to $2.5 \mathrm{~mL}$ with acetonitrile and filtered through a $0.45 \mu \mathrm{m}$ membrane for HPLC analysis. Histamine standard was also derivatized with dansyl chloride as described above. The quantification of histamine was carried out using an Agilent 1200 HPLC unit (Agilent technologies Co., Santa Clara, USA) with a Zorbax Extend-C18 column $(4.6 \times 150 \mathrm{~mm})$. The sample was eluted with a binary solution consisting of ultrapure water (solvent A) and acetonitrile (solvent B) according to the optimized gradient elution program described as follows: linear increase of solvent B from $60 \%$ at the beginning to $100 \%$ within $15 \mathrm{~min}$, then decrease to $60 \%$ in $5 \mathrm{~min}$. The flow rate was $1.0 \mathrm{~mL} / \mathrm{min}$ and the column temperature was set as $30^{\circ} \mathrm{C}$. A sample volume of $20 \mu \mathrm{L}$ was injected and the detecting wavelength was $254 \mathrm{~nm}$. A suitable calibration curve was prepared using standard solution of histamine.

\subsection{Statistical analysis}

The experimental results were expressed as means \pm standard deviation (SD) of triplicates. Statistical analysis was performed using Fisher's $F$-test and $p<0.05$ was regarded as significant.

\section{Results and discussion}

E. aerogenes is one of main histamine-producing bacteria, which can cause fish spoilage and even lead to some food borne diseases, such as scombroid poisoning (Hwang et al., 2010). As shown in Figure 1, change of bacterial count in chub mackerel inoculated with E. aerogenes DL-1 during storage at 4,20 and $37^{\circ} \mathrm{C}$ was analyzed to evaluate effect of storage temperature on bacterial growth. In the first $6 \mathrm{~h}$ of storage at $37^{\circ} \mathrm{C}$, a low level of growth was detected with little increase of bacterial number, followed by a dramatic increase in bacterial count from 6 to $24 \mathrm{~h}$, reaching a peak value of $9.66 \mathrm{log} \mathrm{CFU} / \mathrm{g}$ at $24 \mathrm{~h}$. Then a slight decline occurred, and a relatively high

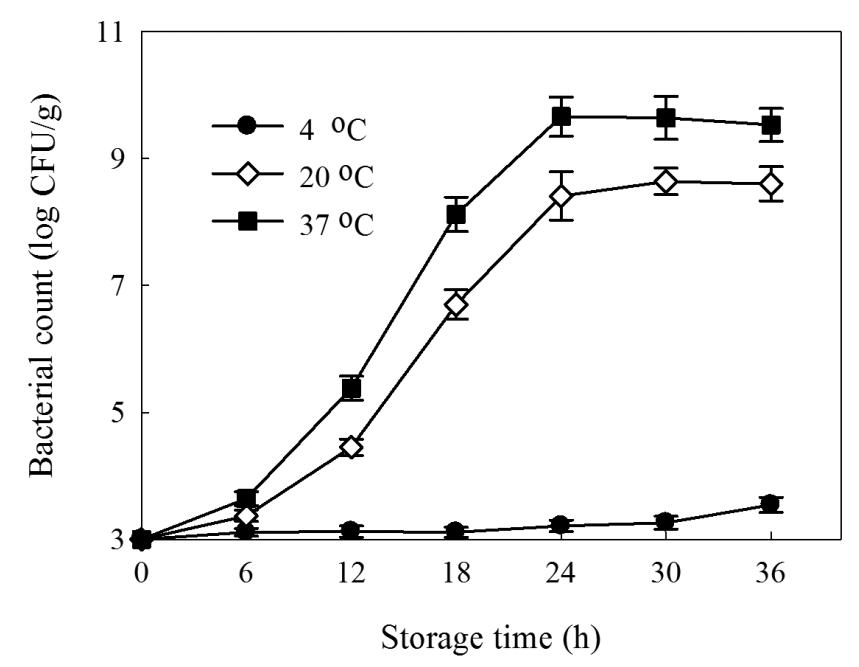

Figure 1. Change of bacterial count in chub mackerel inoculated with E. aerogenes DL-1 at $3.0 \log \mathrm{CFU} / g$ during storage at 4,20 and $37^{\circ} \mathrm{C}$. Values are means \pm SD of three independent determinations. 
level of bacterial count was retained until the end of storage. The similar change of bacterial count was observed in chub mackerel during storage at $20^{\circ} \mathrm{C}$, and bacterial count reached a peak value of $8.64 \log \mathrm{CFU} / \mathrm{g}$ at $30 \mathrm{~h}$. However, no obvious variation was found during the first $30 \mathrm{~h}$ of storage at $4{ }^{\circ} \mathrm{C}$. Until $36 \mathrm{~h}$, bacterial count slightly increased but not exceeding $3.6 \log \mathrm{CFU} / \mathrm{g}$, which was significantly lower $(p<0.05)$ than those of other storage temperatures $\left(20\right.$ and $\left.37^{\circ} \mathrm{C}\right)$. This result was similar to that previously reported by Fernández-No et al. (2011).

Histamine in marine fishes is formed mainly through the decarboxylation of l-histidine by exogenous HDC released by some histamine-producing bacteria (Chong et al., 2014). Therefore, higher HDC activity is associated with more accumulation of histamine (Kung et al., 2006). As shown in Figure 2, HDC activity showed no changes in chub mackerel during storage at $4{ }^{\circ} \mathrm{C}$. However, HDC activity began to increase slowly from 0 to 2.35 and $4.33 \mathrm{U} / \mathrm{g}$ during the first $12 \mathrm{~h}$ of storage at 20 and $37^{\circ} \mathrm{C}$, respectively. Then, HDC activity increased markedly to the highest level of 23.21 and $31.68 \mathrm{U} / \mathrm{g}$ at $24 \mathrm{~h}$ respectively until staying at this level. Furthermore, throughout the storage period, HDC activity in chub mackerel stored at $37^{\circ} \mathrm{C}$ increased more $(p<0.05)$ than those stored at $20^{\circ} \mathrm{C}$.

Figure 3 showed time course of histamine production in chub mackerel inoculated with $E$. aerogenes during storage at different temperatures. Rapid increase in accumulation of histamine occurred after $12 \mathrm{~h}$ of storage, when E. aerogenes grown in chub mackerel with high storage temperature $\left(20\right.$ and $\left.37^{\circ} \mathrm{C}\right)$. However, histamine content did not further increase when storage time was extended from 24 to $36 \mathrm{~h}$. Maximum accumulation of histamine ( 242.6 and $295.5 \mathrm{mg} / 100 \mathrm{~g}$ ) was achieved at $36 \mathrm{~h}$ of storage at 20 and $37^{\circ} \mathrm{C}$. Chub mackerel stored at $37^{\circ} \mathrm{C}$ had significantly higher $(p<0.05)$ amounts of histamine than those stored at $20^{\circ} \mathrm{C}$. In contrast, inhibitory effect on histamine formation occurred when storage temperature was at $4{ }^{\circ} \mathrm{C}$. During the cold storage, the variety of histamine content was slight. The present results showed that low storage temperature $\left(4{ }^{\circ} \mathrm{C}\right)$ could effectively prevent the synthesis of histamine. Similarly, Lee et al. (2012) reported that histamine formation was controlled by cold storage of tuna dumpling stuffing at $4{ }^{\circ} \mathrm{C}$. Thus, cold storage could reduce histamine production and was suitable for preservation of marine fishes.

The formation of histamine in marine fishes depends on various factors, such as l-histidine content in fish, the presence of bacterial HDC and favourable environmental conditions (Hu et al., 2012). Usually, the levels of l-histidine in marine fishes would gradually increase with prolonged storage time due to proteolysis by endogenous and exogenous proteases (Huang et al., 2010; Hungerford, 2010). Then, histamine can be formed through the microbial decarboxylation of 1-histidine during storage. However, the amount of histamine formed in marine fishes may be strongly influenced by the environmental conditions, especially storage temperature. In the present study, histamine content in chub mackerel kept unchanged during cold storage $\left(4^{\circ} \mathrm{C}\right)$ for $36 \mathrm{~h}$, while large amounts of histamine occurred during storage at 20 and $37^{\circ} \mathrm{C}$. This indicated that storage temperature was the principal effect on accumulation of histamine, which agreed with results reported by Middlebrooks et al. (1988) and Torido et al. (2012).
It is important to realize that presence of histamine in marine fishes does not change the color or smell of fish because histamine is a colorless and odorless compound (Aberoumand, 2014; García-Tapia et al., 2013; Lin et al., 2012). Although a slight change in the fish color was observed after $36 \mathrm{~h}$ of storage in the experiment, no foul odor was detected with histamine accumulation. Therefore, when these histamine-producing bacteria are present in fish, there is significant risk of undetected accumulation of large amounts of histamine before the fish decay (Tsai et al., 2007). In the present study, bacterial growth and histamine formation were controlled for $36 \mathrm{~h}$ by cold storage of fish samples at $4{ }^{\circ} \mathrm{C}$. However, the chill chub mackerel were thawed and stored at 20 or $37^{\circ} \mathrm{C}$, histamine would start to accumulate rapidly. Thus, even with sensorial alterations, the consumption of sterilized fisheries products would be an alternative in order to assure seafood safety.

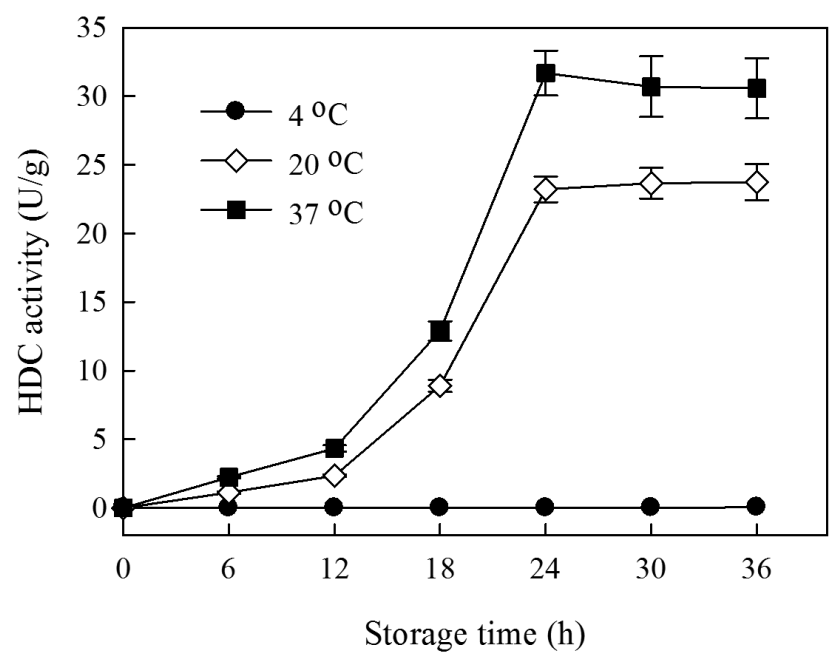

Figure 2. Change of HDC activity in chub mackerel inoculated with E. aerogenes DL- 1 at $3.0 \log \mathrm{CFU} / g$ during storage at 4,20 and $37^{\circ} \mathrm{C}$. Values are means \pm SD of three independent determinations.

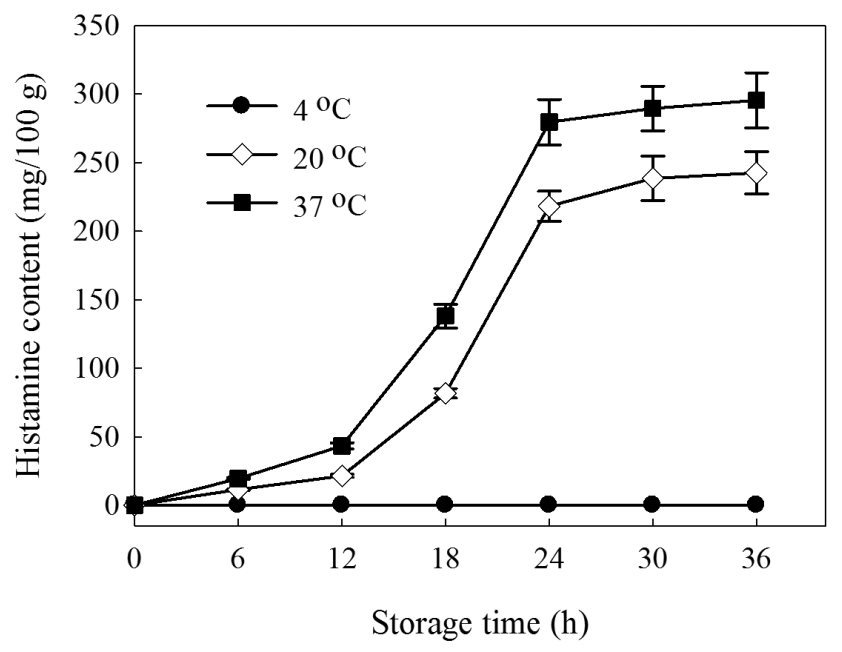

Figure 3. Change of histamine content in chub mackerel inoculated with E. aerogenes DL- 1 at $3.0 \log \mathrm{CFU} / g$ during storage at 4,20 and $37^{\circ} \mathrm{C}$. Values are means \pm SD of three independent determinations. 


\section{Conclusions}

In this study, bacterial count, HDC activity and histamine content in chub mackerel inoculated with E. aerogenes stored at 4,20 and $37^{\circ} \mathrm{C}$ were investigated. Results showed that bacterial count of E. aerogenes and amount of histamine rapidly increased from 12 to $24 \mathrm{~h}$ when samples were kept at 20 and $37^{\circ} \mathrm{C}$. Cold storage $\left(4^{\circ} \mathrm{C}\right)$ could delay microbial growth, fish spoilage and histamine accumulation. Results from this study indicated that cold or ice storage of chub mackerel could be an effective means to control histamine level in fish.

\section{Acknowledgements}

This work was supported by the National Natural Science Foundation of China (No. 31301421) and Program for Liaoning Excellent Talents in University (No. LJQ2015031).

\section{References}

Aberoumand, A. (2014). Preliminary studies on nutritive and organoleptic properties in processed fish fillets obtained from Iran. Food Science and Technology, 34(2), 287-291. http://dx.doi.org/10.1590/fst.2014.0042.

Bae, J. H., \& Lim, S. Y. (2012). Chemical composition, antiproliferative and antioxidant properties of lipid classes in ordinary and dark muscles from chub mackerel (Scomber japonicus). Food and Chemical Toxicology, 50(3-4), 823-828. http://dx.doi.org/10.1016/j. fct.2011.12.038. PMid:22248865.

Chong, C. Y., Abu Bakar, F., Rahman, R. A., Bakar, J., \& Zaman, M. Z. (2014). Biogenic amines, amino acids and microfloras changes in Indian mackerel (Rastrellinger kanagurta) stored at ambient $\left(25-29^{\circ} \mathrm{C}\right)$ and ice temperature $\left(0^{\circ} \mathrm{C}\right)$. Journal of Food Science and Technology, 51(6), 1118-1125. http://dx.doi.org/10.1007/s13197012-0621-3. PMid:24876644.

Fadhlaoui-Zid, K., Curiel, J. A., Landeta, G., Fattouch, S., Reverón, I., Rivas, B., Sadok, S., \& Muñoz, R. (2012). Biogenic amine production by bacteria isolated from ice-preserved sardine and mackerel. Food Control, 25(1), 89-95. http://dx.doi.org/10.1016/j.foodcont.2011.10.032.

Fernández-No, I. C., Böhme, K., Calo-Mata, P., \& Barros-Velázquez, J. (2011). Characterisation of histamine-producing bacteria from farmed blackspot seabream (Pagellus bogaraveo) and turbot (Psetta maxima). International Journal of Food Microbiology, 151(2), 182-189. http://dx.doi.org/10.1016/j.ijfoodmicro.2011.08.024. PMid:21925757.

García-Tapia, G., Barba-Quintero, G., Gallegos-Infante, J. A., Aguilar, R. P., Ruíz-Cortés, J. A., \& Ramírez, J. A. (2013). Influence of physical damage and freezing on histamine concentration and microbiological quality of yellowfin tuna during processing. Food Science and Technology, 33(3), 463-467. http://dx.doi.org/10.1590/ S0101-20612013005000061.

Hsu, H. H., Chuang, T. C., Lin, H. C., Huang, Y. R., Lin, C. M., Kung, H. F., \& Tsai, Y. H. (2009). Histamine content and histamine-forming bacteria in dried milkfish (Chanos chanos) products. Food Chemistry, 114(3), 933-938. http://dx.doi.org/10.1016/j.foodchem.2008.10.040.

Hu, Y., Huang, Z., Li, J., \& Yang, H. (2012). Concentrations of biogenic amines in fish, squid and octopus and their changes during storage. Food Chemistry, 135(4), 2604-2611. http://dx.doi.org/10.1016/j. foodchem.2012.06.121. PMid:22980848.

Huang, Y. R., Liu, K. J., Hsieh, H. S., Hsieh, C. H., Hwang, D. F., \& Tsai, Y. H. (2010). Histamine level and histamine-forming bacteria in dried fish products sold in Penghu Island of Taiwan. Food Control, 21(9), 1234-1239. http://dx.doi.org/10.1016/j.foodcont.2010.02.008.
Hungerford, J. M. (2010). Scombroid poisoning: a review. Toxicon, 56(2), 231-243. http://dx.doi.org/10.1016/j.toxicon.2010.02.006. PMid:20152850.

Hwang, C. C., Lee, Y. C., Huang, Y. R., Lin, C. M., Shiau, C. Y., Hwang, D. F., \& Tsai, Y. H. (2010). Biogenic amines content, histamine-forming bacteria and adulteration of bonito in tuna candy products. Food Control, 21(6), 845-850. http://dx.doi.org/10.1016/j.foodcont.2009.11.011.

Kim, J. Y., Kim, D., Park, P., Kang, H. I., Ryu, E. K., \& Kim, S. M. (2009). Biogenic amine formation and bacterial contribution in fish, squid and shellfish. Food Chemistry, 116(1), 87-92. http://dx.doi. org/10.1016/j.foodchem.2009.02.010. PMid:25214333.

Konagaya, Y., Kimura, B., Ishida, M., \& Fujii, T. (2002). Purification and properties of a histidine decarboxylase from Tetragenococcus muriaticus, a halophilic lactic acid bacterium. Journal of Applied Microbiology, 92(6), 1136-1142. http://dx.doi.org/10.1046/ j.13652672.2002.01664.x. PMid: 12010554.

Kung, H. F., Lee, Y. H., Teng, D. F., Hsieh, P. C., Wei, C. I., \& Tsai, Y. H. (2006). Histamine formation by histamine-forming bacteria and yeast in mustard pickle products in Taiwan. Food Chemistry, 99(3), 579-585. http://dx.doi.org/10.1016/j.foodchem.2005.08.025.

Lee, Y. C., Kung, H. F., Lin, C. S., Hwang, C. C., Lin, C. M., \& Tsai, Y.H. (2012). Histamine production by Enterobacter aerogenes in tuna dumpling stuffing at various storage temperatures. Food Chemistry, 131(2), 405-412. http://dx.doi.org/10.1016/j.foodchem.2011.08.072.

Li, Y., Chen, X., Chen, C., Ge, J., Ji, R., Tian, R., Xue, P., \& Xu, L. (2014). Dispersal and survival of chub mackerel (Scomber Japonicus) larvae in the East China Sea. Ecological Modelling, 283, 70-84. http://dx.doi. org/10.1016/j.ecolmodel.2014.03.016.

Lin, C. M., Kung, H. F., Huang, Y. L., Huang, C. Y., Su, Y. C., \& Tsai, Y.-H. (2012). Histamine production by Raoultella ornithinolytica in canned tuna meat at various storage temperatures. Food Control, 25(2), 723-727. http://dx.doi.org/10.1016/j.foodcont.2011.12.019.

Middlebrooks, B. L., Toom, P. M., Douglas, W. L., Harrison, R. E., \& McDowell, S. (1988). Effects of storage time and temperature on the microfloras and amine development in Spanish mackerel (Scomberomorus maculatus). Journal of Food Science, 53(4), 10241029. http://dx.doi.org/10.1111/j.1365-2621.1988.tb13522.x.

Naila, A., Flint, S., Fletcher, G. C., Bremer, P. J., \& Meerdink, G. (2012). Histamine stability in Rihakuru at $-80,4$ and $30^{\circ} \mathrm{C}$. Food Chemistry, 135(3), 1226-1229. http://dx.doi.org/10.1016/j.foodchem.2012.05.066. PMid:22953847.

Rodtong, S., Nawong, S., \& Yongsawatdigul, J. (2005). Histamine accumulation and histamine-forming bacteria in Indian anchovy (Stolephorus indicus). Food Microbiology, 22(5), 475-482. http:// dx.doi.org/10.1016/j.fm.2004.08.009.

Torido, Y., Takahashi, H., Kuda, T., \& Kimura, B. (2012). Analysis of the growth of histamine-producing bacteria and histamine accumulation in fish during storage at low temperatures. Food Control, 26(1), 174177. http://dx.doi.org/10.1016/j.foodcont.2012.01.009.

Tsai, Y. H., Kung, H. F., Chen, H. C., Chang, S. C., Hsu, H. H., \& Wei, C. I. (2007). Determination of histamine and histamine-forming bacteria in dried milkfish (Chanos chanos) implicated in a foodborne poisoning. Food Chemistry, 105(3), 1289-1296. http://dx.doi. org/10.1016/j.foodchem.2007.03.018.

Zou, Y., Hu, W., Jiang, A., \& Tian, M. (2015). Partial purification and characterization of a novel histidine decarboxylase from Enterobacter aerogenes DL-1. Preparative Biochemistry \& Biotechnology, 45(6), 605615. http://dx.doi.org/10.1080/10826068.2014.940541. PMid:25036745. 